\title{
The development of chemistry practicum e-module based on simple-practice
}

\author{
Nelius Harefa ${ }^{1, *}$ and Leony Sanga Lamsari Purba ${ }^{1}$ \\ 'Department of Chemistry Education, Faculty of Teacher Training and Education, Universitas Kristen Indonesia, \\ Jakarta 13630, Indonesia
}

${ }^{*}$ Corresponding author: (NH), nelius.harefa@uki.ac.id

DOI: 10.24114/jpkim.vlli3.15739

Received: 14 November 2019; Accepted: 4 December 2019

Abstract:

Practicum is an important element in chemistry. In chemistry learning with practical methods students are given the opportunity to be creative, find, or prove a phenomenon that he experienced and the concepts his learned. Therefore, it is important to develop the learning method using practicum to accommodate the progress and needs of the times so that learning is close to students so that learning becomes meaningful. In this research, the development of digital integrated chemistry practicum modules based on simple practice is carried out. The research sample consisted of 248 students and 26 chemistry teachers, and was validated by 3 expert judges. In the initial stage, the module developed is validated by expert judges. The validation results show that the module is categorized as valid in terms of content eligibility, language feasibility, and presentment eligibility with an average score of 3.81 (scale 4 ). In the final stage, a module testing is conducted for chemistry students and teachers in the form of collecting responses. Chemistry teacher response results indicate that the module is feasible to be used as a source of student learning on chemistry practicum class $\mathrm{XI}$ high school even semester with an average score of 3.78 (scale 4). The results of the students' responses showed that the module was appropriate for them to use as a source of learning on chemistry practicum with an average score of 3.79 (scale 4). The results of student responses on the presentment eligibility aspect showed the highest value of 3.98 (scale 4), the module developed was presented digitally integrated which can be accessed online.

Keywords: Chemistry; e-module; practicum; simple-practice

\section{Introduction}

Indonesian curriculum 2013 and national curriculum is a curriculum for elementary and secondary school strata that requires student-centered learning system and the teacher acts as a facilitator. This curriculum is considered appropriate to accommodate the industrial revolution 4.0 era, and also accommodate the necessary of millennial students. An important point of the development of this era is the era of digitalization. The era of digitalization directly contributes to the changing order of life including education, which means that student-centered learning designs must transform to accommodate the digitalization era. The demand is actually not a problem, considering that most students in Indonesia today are millennial student's, one of which is digital literacy.

The implementation of a digital integrated learning system can affect the cognitive, affective, and psychomotor aspects of students. Harefa et al. (2019), reports that integrated digital learning by utilizing the sway Microsoft 365 application affects students' learning outcomes. Students' learning outcomes that are integrated with sway Microsoft 365 are higher than 
students' learning outcomes that are taught using conventional methods utilizing handouts. Kahoot! assisted digital integrated learning can increase students' motivation to obtain the learning outcomes optimum in chemistry learning (Purba et al. 2019). Purba et al. (2018), reports that digital integrated learning assisted with macromedia flash can increase students' activity for learning compared to conventional learning assisted with handouts. The increase in students' activity directly affects students' learning outcomes, where students who have high learning activities will get better learning outcomes compared to students with low learning activities.

Digital based learning accommodates practical and fun learning without reducing the essence of learning itself. Digital integrated learning based on FORFIS applications can improve students' analogous skills (Sari et al. 2018). The establishment of analogous skills can stimulate the formation of self-assessing skills. Digital integrated learning can stimulate the formation of scientific skills of students in conducting scientific methods (Cahyani and Hendriani, 2017), and the formation of critical thinking skills (Wardani et al. 2017). The establishment of scientific skills and thinking skills of students will stimulate an increase in student learning outcomes (Nadeak, 2018). In general, students are ready to welcome the era of digitalization. Thus, it is necessary to optimize the role of the teacher as a facilitator in accommodating the era of digitalization so that student-centered learning becomes more meaningful and can contribute significantly to the development of education in Indonesia.

Science learning like chemistry is the learning that actually provides opportunities and accommodates student-centered learning, especially through learning in the laboratory (practicum). Practicum (practice) is learning where students are given the opportunity to create, search for, or prove a phenomenon that they experience and the concepts they learn. Practical learning methods can improve cognitive, affective, and psychomotor aspects. Specifically, learning with this method can improve students' problem solving skills and can stimulate the establishment of motivation (Abadi and Bahriah, 2016) to find, prove, analyze, experience themselves, and draw conclusions from a concept they are learning (Harefa, 2018). In addition, learning with practicum methods can improve students' critical thinking skills (Kurniawati et al. 2015), and practice the science process (Suryaningsih, 2017).

Practicum method is one of the right methods to increase students' understanding of an abstract concept. Increased understanding of these concepts can improve student learning outcomes (Nuraida and Nisa, 2017). With practicum methods, students' curiosity can be significantly, increasing curiosity can directly affect student learning outcomes. Students who have high curiosity will have motivation to study harder, so that students will be able to improve their learning outcomes (Pamungkas et al. 2017). In general, learning by practicum method gives meaning to students that influence the improvement of skills and learning outcomes.

Learning materials in practical methods are flexible but must be able to accommodate the concept of a material. Generally, these materials can be created referring to the situation, conditions, facilities and infrastructure, culture, ethnicity, and natural resources of an area. That's the point, learning with practicum methods can be a place of creation for teachers as learning facilitators so that concepts that are not understood by students theoretically can be explored through practicum. One practicum material that can be created to stimulate students' understanding of a material is a simple practice (Susilowati, 2016). Simple practice can make it easier for students to understand a theoretical concept intact (Lubis et al. 2018). By applying simple practices, students' mindset will change from complicated concepts theoretically to become simpler (Waris et al. 2017). These simple practices continue to stimulate the formation of students' thinking skills. With the establishment of these skills, simple practice can be used as a medium for student practice (Widayanti and Yuberti, 2018). Thus, it is important to develop 
practical based practical material on chemistry learning specifically abstract material so that concepts can be understood in their entirety and are enjoyable for students.

The important component of practical learning is the availability of practical modules. The practicum modules need to be developed to accommodate the development of the era and to accommodate learning models and strategies (Widayanti et al. 2018). Nowadays, practicum modules are important to be developed to accommodate the demands of the era namely the digitalization era so that practicum can accommodate students to learn, to find and be able to solve problems related to the current era (Purba et al. 2015). Situmorang et al. (2015), reports that teaching materials developed based on multimedia can improve chemistry teaching and learning activities, learning chemistry becomes easier, efficient, and student centered learning. Innovative teaching materials can also increase student motivation to learn, so an increase in student learning outcomes.

Practicum modules can also be developed to stimulate student entrepreneurship styles (Nofiana et al. 2015). Utilization of digital integrated practicum modules will foster students' creativity to transform an object into another object that is more useful by utilizing chemical concepts that are practiced. Creativity makes a product to be an entrepreneur is very important to be developed in the era of digitalization given the wide openness to information. In addition, practicum modules must also be developed to accommodate the environment, considering that environmental issues are one of the priority issues, especially those related to pollution so that the character of environmental love can be formed in students (Susanti et al. 2018). Digital integrated practicum modules will be very effective to stimulate the formation of environmental love character because digital integrated practicum modules can be created by combining multimedia content. Therefore, it is necessary to develop a digital integrated practicum module as a contribution to the teacher as a learning facilitator while simultaneously accommodating digitalized integrated student learning systems.

\section{Methods}

This study consists of five stages, including: the first stage, an analysis of the needs of students, teachers, and material is carried out. The second stage, the manufacture of products based on needs analysis. The third stage, the validation of expert judges is carried out which includes material validation and product validation, at this stage product revisions are carried out to accommodate the suggestions of expert judges. In the fourth stage, a trial was conducted which included student and teacher responses and the results of student evaluations (including minor scale tests and major scale tests), at this stage a product revision was carried out to accommodate the results of the trials. The fifth stage, product manufacturing is carried out accommodating validation from experts, student and teacher responses, and the results of student evaluations, at this stage the final product of the research results is obtained.

The research sample is students of class XI MIPA 1 and XI MIPA 2 at Yadika 9 High School in Bekasi, class XI MIPA 1 and XI MIPA 2 at SMA 1 CawangBaru Jakarta, and class XI IPA at SMA Abdi SiswaBintaro, Tangerang and social science student's in chemical specialization of the three schools totaling 248 student's were selected through a purposive sampling technique. Teacher responses were collected from chemistry teachers who were members of the South Tangerang chemistry teacher forum totaling 26 teachers.

Materials that are sampled for making e-module are class $\mathrm{XI}$ chemicals material: identification of acid and base compounds; equilibrium solution; buffer solution; acid-base titration; and colloidal system. Research data were analyzed using SPSS 21 and Microsoft Excel for windows. The flowchart of this research is show at Fig 1. 


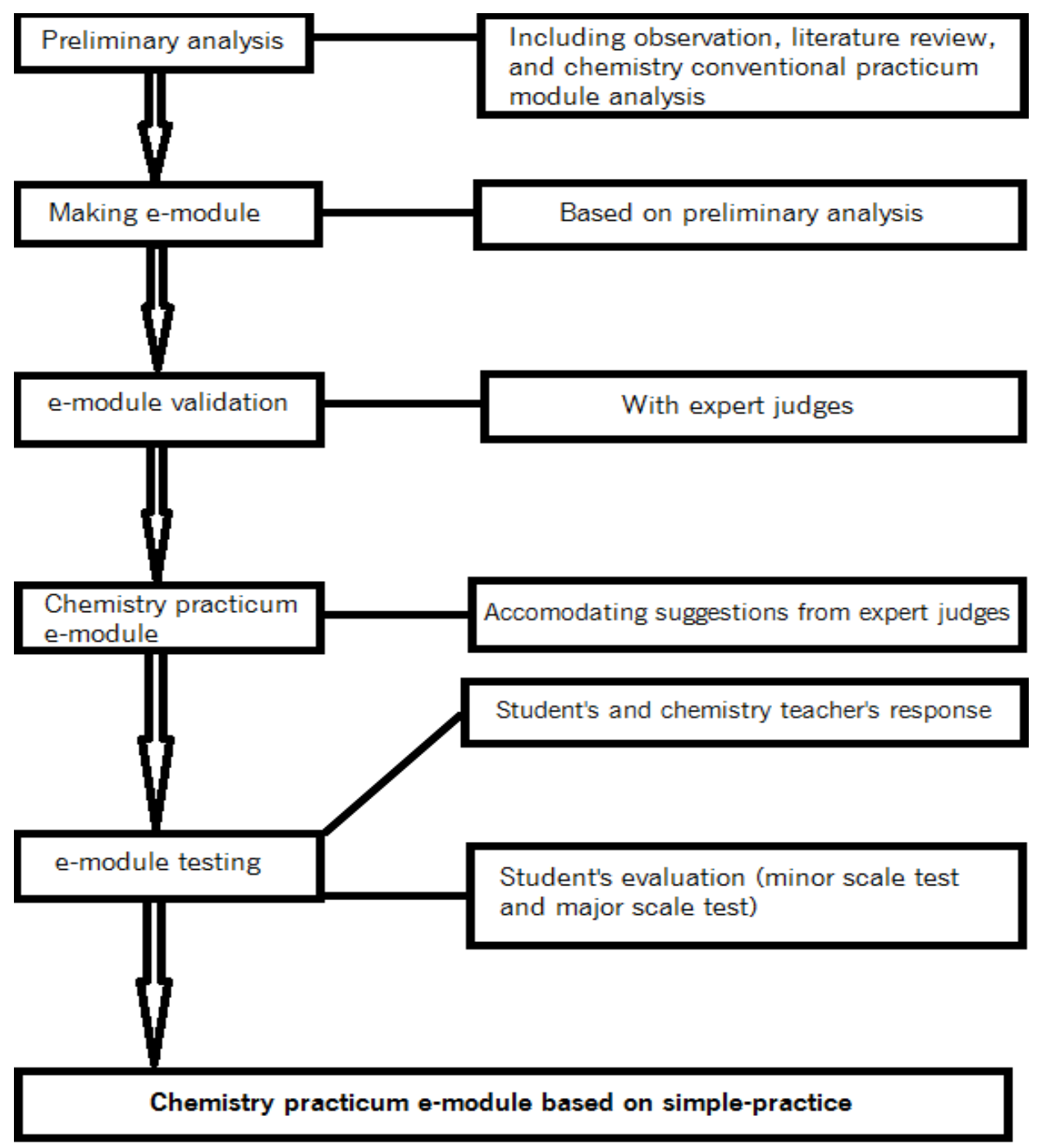

Fig 1. Research flowchart

\section{Results}

This study aims to obtain a module for chemical practicum integrated digital based on simple practice. Practical module materials include: identification of acid and base compounds; equilibrium solution; buffer solution; acid-base titration; and colloidal system. The module is expected to help millennial students to learn more efficiently, interestingly, and meaningfully. The initial stage of the development of this module is an analysis of the existing chemistry practicum modules that are used by high school students in grade Xl even semester. The initial analysis was carried out as a basis for the development of a chemistry practicum e-module based on simple-practice.

Chemistry practice e-module based on simple-practice that has been developed is validated by expert judges based on the BSNP standard questionnaire which includes content eligibility test, language feasibility test, and presentment eligibility test. The revision of the chemistry practicum e-module based on simple-practice was carried out to accommodate criticism and suggestions from expert validators. In the final stage, standardization of chemistry practicum emodule based on simple-practice by conducting a minor scale test, major scale test, student response, and teachers response. Standardization is done by giving questionnaires to students 
and teachers to get their opinions on the module. Questionnaire is equipped with indicators, each indicator is equipped with a statement, and each statement is equipped with a choice in the form of figures, the figure is then used as a score (minimum score is 1 and maximum score is 4) which is the research data. The scores are summed and averaged to obtain respondent data on the feasibility of the module being developed.

\section{Analysis of available chemistry practicum modules}

The initial stage in this study is the analysis of chemistry practicum modules that are available and used by high school students in grade $\mathrm{XI}$ on even semester. The analysis was carried out by giving a score (scale 4) based on the BSNP instrument questionnaire which included content eligibility test, language feasibility test, and presentment eligibility test. The test result is shown in Table 1.

Table 1

Chemistry practicum conventional module analysis

\begin{tabular}{llc}
\hline No. & Aspect & Average score \\
\hline 1. & Content eligibility & 2.48 \\
2. & Language feasibility & 2.82 \\
3. & Presentment eligibility & 2.18 \\
\hline
\end{tabular}

Based on Table 1 , it is shown that the conventional chemistry practicum module used by students is categorized as feasible with an average score of content eligibility test, language feasibility test, and presentment eligibility test of 2.49. Based on these data, researchers conducted development in terms of content, language, and presentment through a scientific and integrated digital approach. Thus, the development of chemical practicum modules is dominant in terms of presentation.

\section{Analysis and standardization of chemical practicum modules developed}

The next step after the analysis of the available practicum modules is the development of a digital integrated practicum module based on a simple practice. The development is carried out referring to the feasibility of the content, the feasibility of the language, and the feasibility of the presentment based on conventional chemistry practice module analysis. Development emphasizes the feasibility of digital based presentment.

The chemical materials that are sampled for module development are even semester $\mathrm{XI}$ high school chemistry materials which include: identification of acid and base compounds; equilibrium solution; buffer solution; acid-base titration; and colloidal system. The development is carried out based on syllabus, semester learning plans, and even semester XI high school chemistry textbooks. Development is carried out by integrating scientific methods with a student centered learning approach and can be accessed by utilizing the internet network.

After the module has been developed, module standardization is based on the BSNP standard questionnaire by expert judges, namely: (1) FKIP UKI chemistry education lecturer who has experience teaching basic chemistry courses for more than 5 years; (2) chemistry teacher at SMA N 14 Jakarta who has more than 5 years teaching experience; and (3) lecturers of the Faculty of Engineering UKI who have experience in teaching Information, Communication, and Technology (ICT) courses for more than 5 years. Expert judges score (scale 4) on each statement from the three aspects assessed, namely: the appropriateness of the content, the appropriateness of the language, and the appropriateness of the presentment. The results of the validation of the first expert who is a chemistry education lecturer in FKIP UKI who has experience teaching basic chemistry courses for more than 5 years is shown in Table 2.The 
result of the validation of the second expert who is a chemistry teacher at SMA N 14 Jakarta who has teaching experience of more than 5 years is shown in Table 3.

Table 2

Expert judges (lecturer) validation result

\begin{tabular}{lllc}
\hline No. & Aspect & Average score & Declaration \\
\hline 1. & Content eligibility & 3.82 & Valid \\
2. & Language feasibility & 3.68 & Valid \\
3. & Presentment eligibility & 3.72 & Valid \\
\hline
\end{tabular}

Table 3

Expert judges (chemistry teacher) validation result

\begin{tabular}{lllc}
\hline No. & Aspect & Average score & Declaration \\
\hline 1. & Content eligibility & 3.86 & Valid \\
2. & Language feasibility & 3.78 & Valid \\
3. & Presentment eligibility & 3.92 & valid \\
\hline
\end{tabular}

The third expert judge who is a lecturer in the Faculty of Engineering UKI who has experience teaching ICT subjects more than 5 years became a media expert in this study. The standardization carried out is focused on the standardization of the presentation related to the media used. Based on the assessment provided, the module developed is valid with an average score of 3.86.After the validation data, suggestions, and input from expert judges are obtained, the module is then revised to accommodate the suggestions and input of the expert judges before the testing phase is conducted.

Chemistry teacher's response to chemistry practicum e-module is based on simple-practice

The next step which is conducted after chemistry practicum e-module based on simple-practice is declared valid by expert judges is to test chemistry practicum e-module based on simplepractice to chemistry teachers. The testing data collection was carried out by asking for the response of 26 chemistry teachers joined in the South Tangerang chemistry teacher forum. The response was based on the BSNP standard questionnaire which included three aspects, namely: the appropriateness of the content, the appropriateness of the language, and the appropriateness of the presentment. Each aspect consists of several statements that are accompanied by a score (minimum score is 1 and maximum score is 4). The responses of the chemistry teachers are shown in Table 4.

Table 4

Chemistry teacher responses

\begin{tabular}{lllc}
\hline No. & Aspect & Average score & Declaration \\
\hline 1. & Content eligibility & 3.72 & Feasible \\
2. & Language feasibility & 3.68 & Feasible \\
3. & Presentment eligibility & 3.96 & Feasible \\
\hline
\end{tabular}

Based on data from three aspects, chemistry practicum e-module based on simple-practice is declared valid. That is, chemistry practicum e-module based on simple-practice is proper to be used as a learning resource in supporting the learning process of chemistry in the laboratory.

\section{Student responses to chemistry practicum e-module based on simple-practice}

The last step carried out in this research is the testing of chemistry practicum e-module based on simple-practice to students. Testing of students is important because students are direct 
users of the modules developed. The trial was conducted by asking students to respond to chemistry practice e-module based on simple-practice. The response is based on the BSNP standard questionnaire which includes three aspects, namely: the appropriateness of the content, the appropriateness of the language, and the appropriateness of the presentment. Each aspect consists of several statements that are accompanied by a score (minimum score is 1 and maximum score is 4). The testing samples were students of class XI MIPA 1 and XI MIPA 2 at Yadika 9 High School Bekasi, class XI MIPA 1 and XI MIPA 2 at SMA 1 CawangBaru jakarta, and class XI IPA at SMA Abdi SiswaBintaro, Tangerang and social science students in chemical specialization of the three schools, totaling 248 people.The responses of these students are shown in Table 5 .

Table 5

Student's response

\begin{tabular}{lllc}
\hline No. & Aspect & Average score & Declaration \\
\hline 1. & Content eligibility & 3.74 & Feasible \\
2. & Language feasibility & 3.66 & Feasible \\
3. & Presentment eligibility & 3.98 & Feasible \\
\hline
\end{tabular}

Based on data from three aspects, chemistry practicum e-module based on simple-practice is declared valid. That is, chemistry practicum e-module based on simple-practice is feasible to be used as a learning resource in supporting the learning process of chemistry in the laboratory and students can receive chemistry practicum e-module based on simple-practice as one of their learning resources.

\section{Discussion}

Practicum is an important part of chemistry. In learning with practical methods students are given the opportunity to be creative, find, or prove a phenomenon that he experienced and the concepts his learned. Learning materials in practical methods are flexible but must be able to accommodate the concept of a material. Generally, these materials can be created referring to the situation, conditions, facilities and infrastructure, culture, ethnicity, and natural resources of an area. That's the point, learning with practicum methods can be a place of creation for teachers as learning facilitators so that concepts that are not understood by students theoretically can be explored through practicum.

Practicum material that can be created to stimulate students' understanding of a material is a simple practice (Susilowati, 2016). Simple practice can make it easier for students to understand a theoretical concept intact (Lubis et al. 2018; Silaban, 2017). By applying simple practices, students' mindset will change from complicated concepts theoretically to simpler (Waris et al. 2017). These simple practices continue to stimulate the formation of students' thinking skills. With the establisment of these skills, simple practice can be used as a medium for student practice (Widayanti and Yuberti, 2018; Manalu et al. 2018). Thus, it is important to develop a module based simple-practice material on chemistry learning specifically abstract material so that concepts can be understood in their entirety and are enjoyable for students.

In addition to developing material, strategies and methods, practical learning media must also be developed. Media in the learning process has an important role because learning media is the most easily adapted to the times. In this study a digital integrated chemistry lab module was developed based on a simple experiment. Based on student response data, students gave the highest assessment on the aspect of presentation of chemistry practicum e-module based on simple-practice of 3.98 (scale 4). This shows that students are interested in modules that are 
integrated with digital. This fact is supported by research data, where modules are developed integrated digitally.

\section{Conclusion}

Chemistry practicum e-module based on simple-practice is very suitable for use in the era of the industrial revolution 4.0. This module is more practical, easier to use, and more interesting compared to conventional modules (in the form of a paper / book). The response to the indicator shows that the user (student) is a product of the industrial revolution 4.0 era which is the era of digitalization. Students gave a very high response to the aspect of presenting an integrated digital module that is 3.98 (scale 4), the data shows that students are interested in modules that are presented integrated digital/electronic.The module integrated digital (emodule) is a module that is closely related to the readiness of suggestions and infrastructure especially internet availability. Without an internet network, e-modules cannot be used. This is very vulnerable to disruption in the learning process in the laboratory, especially for schools where the facilities and infrastructure are inadequate. This means that the ease of the learning process with e-module, will go hand in hand with increasingly greater challenges and obstacles. Therefore, conventional practicum modules are still needed to anticipate the unpreparedness of the facilities and infrastructure.

\section{Acknowledgments}

A thank you was given to DRPM Ristekdikti who provided the research through Penelitian Kompetitif Nasional category of the Penelitian Dosen Pemula 2019 scheme. Thanks were also given to the Principal, chemistry teacher, administrative staff, and students of Yadika 9 High School Bekasi; Cawang Baru 1 High School, Jakarta; and Abdi Siswa Bintaro High School, Tangerang for their support and good cooperation so that this research can be completed well. Also, a thank you was given to Universitas Kristen Indonesia, Jakarta for supporting the research.

\section{References}

Abadi, S. M., \& Bahriah, E. S. (2016). Motivasi belajar siswa pada materi ikatan kimia melalui metode praktikum. EduChemia (Jurnal Kimia dan Pendidikan), 1(1), 86-97, doi: 10.30870/educhemia.vli1.442

Cahyani, R., \& Hendriani, Y. (2017). Students' multimedia-assisted scientific inquiry ability on the material of reproductive cells. Jurnal Pendidikan IPA Indonesia, 6(2), 265-270, doi: 10.15294/jpii.v6i2.9484

Harefa, N. (2018). Hubungan motivasi belajar terhadap keterampilan pemecahan masalah siswa pada metode praktikum. Jurnal Selaras: Kajian Bimbingan dan Konseling serta Psikologi Pendidikan, 1(1), 28-38.

Harefa, N., Silalahi, N. F. D., Sormin, E., Purba, L. S. L., \& Sumiyati, S. (2019). The difference of students' learning outcomes with project based learning using handout and sway Microsoft 365. Jurnal Pendidikan Kimia, 11(2), 24-30, doi: 10.24114/jpkim.v1li2.14459

Kurniawati, L., Akbar, R. O., \& Misri, M. A. (2015). Pengaruh penerapan metode pembelajaran praktikum terhadap keterampilan berpikir kritis matematika siswa kelas VII SMP N 3 sumber kabupaten Cirebon. EduMa, 4(2), 62-74.

Lubis, F. A., Lubis, J. A., \& Lubis, M. (2018). "PEPRADASE” pelatihan praktikum biologi dengan alat dan bahan sederhana. Martabe: Jurnal Pengabdian Kepada Masyarakat, 1(1), 16-21, doi: 10.31604/jpm.vli1.1621

Manalu, H. C., Silaban, S., \& Hutabarat, W. (2018). The development of teaching materials stoichiometric integrated multimedia easy sketch. Advances in Social Science, Education and Humanities Research, 200, 352-356, doi: 10.2991/aisteel-18.2018.77 
Nadeak, B. (2018). Students' critical thinking skill and its relation with knowledge and experience at medical faculty christian university of indonesia. International Journal of Scientific Engineering and Research (IJSER), 6(1), 100-106.

Nofiana, l., Yulianti, D., \& Riswandi, R. (2015). Pengembangan panduan praktikum kimia berbasis inkuiri terbimbing. Jurnal Teknologi Informasi Komunikasi Pendidikan (Old), 3(5), 46-52.

Nuraida, D., \& Nisa, U. M. (2017). Pengembangan ensiklopedia morfologi, anatomi dan fisiologi pada tumbuhan berkarakter khusus. In Proceeding Biology Education Conference: Biology, Science, Enviromental, and Learning, 14(1), 503-507.

Pamungkas, M. S. H., Mulyani, S., \& Saputro, S. (2017). Penerapan model pembelajaran poe dengan metode praktikum untuk meningkatkan rasa ingin tahu dan prestasi belajar kimia siswa. Jurnal Penelitian Pendidikan, 20(1), 46-60, doi: 10.20961/paedagogia.v20i1.16596

Purba, D. N., Damanik, M., Silaban, S., \& Simatupang, L. (2018). The difference of student's activities and learning outcome with problem based learning using macromedia flash and handout. Jurnal Pendidikan Kimia, 10, 403-408, doi: 10.24114/jpkim.v10i3.12704

Purba, F. J., Muchtar, Z., \& Silaban, R. (2015). Pengembangan penuntun praktikum kimia sesuai model pembelajaran penemuan dan berbasis proyek. Jurnal Penelitian Bidang Pendidikan, 21(1), 21-28, doi: 10.24114/jpp.v21i1.2987

Purba, L. S. L., Sormin, E., Harefa, N., \& Sumiyati, S. (2019). Effectiveness of use of online games kahoot! chemical to improve student learning motivation. Jurnal Pendidikan Kimia, 11(2), 57-66, doi: 10.24114/jpkim.vlli2.14463

Purnomo, H., \&Wilujeng, l. (2016). Pengembangan bahan ajar dan instrument penilaian IPA tema indahnya negeriku penyempurnaan buku guru dan siswa kurikulum 2013. Jurnal Prima Edukasia, 4(1), 67-78, doi: 10.21831/jpe.v4i1.7697

Sari, D. K., Supahar, S., \& Ralmugiz, U. (2018). The influence of android-based isomorphic physics (Forfis) application on analogical transfer and self-diagnosis skill of students at SMA Negeri 3 Kupang. Jurnal Pendidikan IPA Indonesia, 7(2), 154-161, doi: 10.15294/jpii.v7i2.14268

Situmorang, M., Sitorus, M., \&Situmorang, Z. (2015). Pengembangan bahan ajar kimia sma/ma inovatif dan interaktif berbasis multimedia. SEMIRATA 2015, 533-542.

Silaban, S. (2017). Dasar-dasar pendidikan matematika dan ilmu pengetahuan alam. Medan: Harapan Cerdas Publisher.

Suryaningsih, Y. (2017). Pembelajaran berbasis praktikum sebagai sarana siswa untuk berlatih menerapkan keterampilan proses sains dalam materi biologi. Bio Educatio, 2(2), 49-57.

Susanti, J., Enawaty, E., \&Melati, H. A. (2018). Pengembangan penuntun praktikum kimia berbasis lingkungan pada materi asam basa kelas xi ipa. Jurnal Pendidikan dan Pembelajaran, 7(11), 1-10.

Susilowati, N. (2016). Pengenalan sains melalui percobaan sederhana pada anak kelompok B di KB-RA IT Al-Husna Yogyakarta. Pendidikan Guru PAUD S-I, 5(5), 551-560.

Wardani, S., Lindawati, L., \& Kusuma, S. B. W. (2017). The development of inquiry by using androidsystem-based chemistry board game to improve learning outcome and critical thinking ability. Jurnal Pendidikan IPA Indonesia, 6(2), 196-205, doi: 10.15294/jpii.v6i2.8360

Waris, A., Darsikin, D., \& Nurjannah, N. (2017). Pengembangan alat praktikum sederhana konsep listrik magnet untuk siswa smp daerah terpencil. JPFT (Jurnal Pendidikan FisikaT adulako Online), 3(2), 1-7.

Widayanti, W., Yuberti, Y., Irwandani, l., \& Hamid, A. (2018). pengembangan lembar kerja praktikum percobaan melde berbasis project based learning. Jurnal Pendidikan Sains Indonesia (Indonesian Journal of Science Education), 6(1), 24-31, doi: 10.24815/jpsi.v6i1.10908

Widayanti, W., \& Yuberti, Y. (2018). Pengembangan alat praktikum sederhana sebagai media praktikum mahasiswa. JIPFRI (Jurnal Inovasi Pendidikan Fisika dan Risetl Imiah), 2(1), 21-27, doi: 10.30599/jipfri.v2il.161 